\title{
Effect of fertilization, chemical crop protection and sowing density on health status of winter wheat grown in short-time monoculture on light soil
}

\author{
Wpływ nawożenia, chemicznej ochrony roślin i gęstości siewu \\ na zdrowotność pszenicy ozimej uprawianej \\ w krótkotrwałej monokulturze na glebie lekkiej
}

Grzegorz Lemańczyk ${ }^{1}$, Mariusz Piekarczyk ${ }^{2}$

\begin{abstract}
Summary

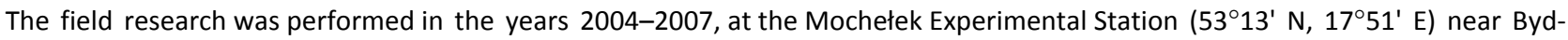
goszcz on good rye complex. The aim of the study was to compare the effect of chemical control (without protection, herbicide, herbicide + fungicide), the mineral fertilisation (147 and $221 \mathrm{~kg} / \mathrm{ha} \mathrm{NPK}$ ) and the sowing density (400 and 600 grains $/ \mathrm{m}^{2}$ ) on the occurrence of diseases in winter wheat cv. Tonacja, grown in short-term monoculture. A tendency of an increase in the symptoms severity of tan spot (Pyrenophora tritici-repentis) intensity and decrease of leaf blotch (Mycosphaerella graminicola) occurrence was noted in the successive wheat growing years in a short-term monoculture. A significant effect of the studied factors was registered and disease severity was dependent on the pesticide treatments. The fewest disease symptoms were recorded after fungicide (flusilazole + carbendazim) and herbicide (iodosulfuron-methyl-sodium) application. The herbicide (iodosulfuron-methyl-sodium) application resulted in increase of disease occurrence, especially leaf blotch and glume blotch (Phaeosphaeria nodorum). Much more symptoms of leaf blotch and powdery mildew (Blumeria graminis) were observed at a higher sowing density. Fewer symptoms of diseases were observed at a lower NPK rate.
\end{abstract}

Key words: winter wheat, diseases, fungi, plant protection, fungicide, herbicide, fertilizer, sowing density

\section{Streszczenie}

Badania polowe przeprowadzono w latach 2004-2007, w Stacji Badawczej Mochełek (53 $\left.13^{\prime} \mathrm{N}, 17^{\circ} 51^{\prime} \mathrm{E}\right)$ koło Bydgoszczy, na glebie kompleksu żytniego dobrego. Ich celem było porównanie wpływu ochrony chemicznej (bez ochrony, herbicyd, herbicyd + fungicyd), dawki nawożenia mineralnego (147 i $221 \mathrm{~kg} N \mathrm{NK} / \mathrm{ha}$ ) i gęstości siewu (400 i 600 ziaren/m²) na występowanie chorób w pszenicy ozimej odmiany Tonacja, uprawianej w krótkotrwałej monokulturze. Zanotowano tendencję do wzrostu nasilenia występowania objawów chorobowych brunatnej plamistości liści (Pyrenophora tritici-repentis) i spadku nasilenia septoriozy paskowanej liści pszenicy (Mycosphaerella graminicola) w kolejnych latach uprawy pszenicy w krótkotrwałej monokulturze. Stwierdzono istotny wpływ badanych czynników na występowanie obserwowanych chorób. Ich nasilenie wyraźnie zależało od zastosowanych środków ochrony roślin. Najniższe nasilenie chorób obserwowano po zastosowaniu fungicydu (flusilazol + karbendazym) i herbicydu (jodosulfuron metylosodowy). Stosowanie samego herbicydu (jodosulfuron metylosodowy) sprzyjało występowaniu chorób, zwłaszcza septoriozy paskowanej liści pszenicy oraz septoriozy plew pszenicy (Phaeosphaeria nodorum). Znacznie więcej symptomów septoriozy paskowanej liści pszenicy oraz mączniaka prawdziwego zbóż i traw (Blumeria graminis) stwierdzono przy zwiększonej gęstości siewu pszenicy. Znacznie mniej objawów chorobowych odnotowano przy niższej dawce nawożenia NPK.

Słowa kluczowe: pszenica ozima, choroby, grzyby, ochrona roślin, fungicyd, herbicyd, nawożenie, gęstość siewu

\footnotetext{
Uniwersytet Technologiczno-Przyrodniczy im. Jana i Jędrzeja Śniadeckich w Bydgoszczy

Kordeckiego 20, 85-225 Bydgoszcz

${ }^{1}$ Zakład Fitopatologii Molekularnej

grzegorz.lemanczyk@utp.edu.pl

${ }^{2}$ Katedra Podstaw Produkcji Roślinnej i Doświadczalnictwa
} 


\section{Wstęp / Introduction}

Istotny wpływ na plonowanie pszenicy ozimej mają warunki agroekologiczne i intensywność technologii. Jej uprawa na glebach gorszej jakości jest bardziej zawodna, a plonowanie w dużym stopniu zależy od stanowiska i warunków pogodowych (Piekarczyk 2010a). Uprawa pszenicy ozimej w monokulturze może prowadzić do nasilenia występowania i szkodliwości niektórych chorób. Szczególnie obserwuje się wzmożone porażenie przez patogeny korzeni i podstawy źdźbła, a niekiedy także liści i kłosów (Mikołajska 1993). Z tego względu koniecznością staje się poszukiwanie rozwiązań przeciwdziałających występowaniu chorób i ich szkodliwości, między innymi poprzez skuteczną ochronę roślin, racjonalne nawożenie oraz odpowiednią obsadę roślin pszenicy.

Oprócz fungicydów na występowanie chorób wpływają również herbicydy. Mogą one oddziaływać bezpośrednio na patogeny, jak również pośrednio poprzez wpływ na mechanizmy odpornościowe rośliny uprawnej, chwasty, antagonizm, mikoryzę, a także skuteczność działania fungicydów (Wisler i Norris 2005). Wpływ ten jest jednak niejednoznaczny. Stosowanie herbicydów może powodować zarówno spadek, jak i wzrost nasilenia chorób (Lévesque i Rahe 1992; Velini i wsp. 2010; Lemańczyk 2012). Wobec nowych przepisów Unii Europejskiej (UE) (Dyrektywa 2009/128/WE), według których państwa członkowskie UE są zobowiązane do wprowadzenia w życie od 1 stycznia 2014 roku zasad integrowanej ochrony roślin, nie można jej ograniczyć tylko do stosowania chemicznych środków ochrony roślin. Należy użyć takich rozwiązań, które będą prowadziły do utrzymania agrofagów na poziomie nieszkodliwym dla rośliny uprawnej i pozwolą uzyskać zdrowy plon przy minimalnych zakłóceniach funkcjonowania ekosystemu rolniczego (Korbas i wsp. 2008).

Celem badań była ocena nasilenia chorób występujących na pszenicy ozimej uprawianej w pierwszym, drugim i trzecim roku monokultury, w warunkach zróżnicowanej ochrony chemicznej, różnej dawki nawożenia NPK oraz gęstości siewu.

\section{Materiały i metody / Materials and methods}

Badania przeprowadzono w Stacji Badawczej w Mochełku, należącej do Uniwersytetu TechnologicznoPrzyrodniczego w Bydgoszczy, na glebie płowej kompleksu żytniego dobrego $\left(53^{\circ} 13^{\prime} \mathrm{N}, 17^{\circ} 51^{\prime} \mathrm{E}\right)$. Pszenicę ozimą odmiany Tonacja wysiewano w krótkotrwałej monokulturze, przez trzy kolejne lata na tym samym polu. Doświadczenie założono po gorczycy białej, uprawianej w plonie głównym na nasiona, w dwóch trzyletnich seriach. Pierwsza seria badań objęła lata 2004-2006, druga - lata 2005-2007. Eksperyment przyjął postać trójczynnikowego, w układzie losowanych i równoważnych podbloków w czterech powtórzeniach, o powierzchni poletek $15 \mathrm{~m}^{2}$. Ziarno zaprawiano zaprawą Raxil $02 \mathrm{DS}$ (tebukonazol) i wysiewano w trzeciej dekadzie września.

Czynnikami doświadczenia były: I czynnik - ochrona roślin: bez ochrony, herbicyd (Huzar 05 WG w dawce
$200 \mathrm{~g} / \mathrm{ha}$ ), herbicyd (Huzar 05 WG w dawce $200 \mathrm{~g} / \mathrm{ha})+$ fungicyd (Alert $375 \mathrm{SC}$ w dawce $1 \mathrm{l} / \mathrm{ha}$ ); II czynnik gęstość siewu: 400 ziaren $/ \mathrm{m}^{2}, 600$ ziaren $/ \mathrm{m}^{2}$; III czynnik nawożenie: $147 \mathrm{~kg} \mathrm{NPK} / \mathrm{ha}(20 \mathrm{~kg} \mathrm{~N} / \mathrm{ha}+17 \mathrm{~kg} \mathrm{P} / \mathrm{ha}+$ $50 \mathrm{~kg} \mathrm{~K} / \mathrm{ha}$ przedsiewnie jesienią, $40 \mathrm{~kg} \mathrm{~N} / \mathrm{ha}$ wiosną w momencie ruszenia wegetacji $+20 \mathrm{~kg} \mathrm{~N} / \mathrm{ha} \mathrm{w}$ fazie strzelania w źdźbło); $221 \mathrm{~kg}$ NPK/ha $(30 \mathrm{~kg} \mathrm{~N} / \mathrm{ha}+26 \mathrm{~kg}$ $\mathrm{P} / \mathrm{ha}+75 \mathrm{~kg} \mathrm{~K} / \mathrm{ha}$ jesienią przedsiewnie, $60 \mathrm{~kg} \mathrm{~N} / \mathrm{ha}$ wiosną w momencie ruszenia wegetacji $+30 \mathrm{~kg} \mathrm{~N} / \mathrm{ha}$ w fazie strzelania w źdźbło).

Chemiczne odchwaszczanie preparatem Huzar 05 WG (jodosulfuron metylosodowy) wykonywano wiosną po ruszeniu wegetacji pszenicy ozimej, natomiast zwalczanie chorób grzybowych przeprowadzano jednokrotnie fungicydem Alert 375 SC (flusilazol + karbendazym) w końcu fazy strzelania w źdźbło. Ocenę zdrowotności wykonano w fazie dojrzałości mlecznej ziarna pszenicy (BBCH 73-75) zgodnie z wytycznymi EPPO (Eurpoean and Mediterrancan Plant Protection Organization). Szacowano procent porażonej przez grzyby powierzchni liścia flagowego i podflagowego oraz kłosów. Uzyskane dane poddano analizie wariancji a istotność różnic pomiędzy średnimi oceniono testem Tukeya na poziomie istotności $\mathrm{p}=0,05$. Do obliczeń zastosowano pakiet programów statystycznych FR-ANALWAR 5. Wyniki przedstawione w pracy są średnimi z obu serii doświadczenia.

\section{Wyniki i dyskusja / Results and discussion}

$\mathrm{Na}$ ocenianych liściach pszenicy ozimej uprawianej na glebie lekkiej w największym nasileniu występowała septorioza paskowana liści pszenicy (Mycosphaerella graminicola), znacznie mniej obserwowano objawów mączniaka prawdziwego zbóż i traw (Blumeria graminis), rdzy brunatnej (Puccinia triticina) i brunatnej plamistości liści (Pyrenophora tritici-repentis). Na kłosach występowała głównie septorioza plew pszenicy (Phaeosphaeria nodorum) (tab. 1-5). W kolejnych latach uprawy pszenicy po sobie stwierdzono coraz więcej objawów brunatnej plamistości liści oraz coraz mniej septoriozy paskowanej liści pszenicy. Dla pozostałych chorób nie zaobserwowano wyraźnych zmian w nasileniu, w zależności od roku uprawy pszenicy po sobie.

$\mathrm{Na}$ niewielki i często niejednoznaczny wpływ przedplonu oraz uprawy pszenicy w monokulturze na występowanie chorób liści i kłosów wskazują również inni autorzy (Mikołajska 1993; Lemańczyk i Jaskulski 2006; Lemańczyk i Piekarczyk 2010). Zwiększone występowanie objawów brunatnej plamistości liści w kolejnych latach uprawy pszenicy po sobie obserwowali także Horoszkiewicz-Janka i wsp. (2012). Fakt ten thumaczy się rozwojem $P$. tritici-repentis na pozostałych po zbiorze resztkach roślin, stanowiących źródło infekcji w następnym sezonie wegetacyjnym. $Z$ drugiej strony w uprawie pszenicy po sobie obserwuje się mniej zwarte łany, co powoduje, że mikroklimat jest mniej sprzyjający dla rozwoju większości patogenów atakujących liście i kłosy.

$\mathrm{Na}$ występowanie chorób w pszenicy ozimej uprawianej na glebie lekkiej statystycznie istotnie wpływała ochrona chemiczna, dawka nawożenia mineralnego oraz 
Tabela 1. Procent powierzchni liści z objawami septoriozy paskowanej liści pszenicy (M. graminicola) - średnio z dwóch serii Table 1. Percentage of wheat leaf surface area with symptoms of leaf blotch (M. graminicola $)$ - mean for two series

\begin{tabular}{|c|c|c|c|c|c|c|c|c|c|c|}
\hline \multirow{3}{*}{$\begin{array}{l}\text { Chemiczna } \\
\text { ochrona roślin } \\
\text { Chemical crop } \\
\text { protection } \\
\text { (I) }\end{array}$} & \multirow{3}{*}{$\begin{array}{l}\text { Gęstość siewu } \\
\text { ziaren } / \mathrm{m}^{2} \\
\text { Sowing density } \\
\text { grains } / \mathrm{m}^{2} \\
\text { (II) }\end{array}$} & \multicolumn{9}{|c|}{ Dawka nawożenia - Fertilizer dose [kg NPK/ha] (III) } \\
\hline & & \multicolumn{3}{|c|}{$\begin{array}{l}\text { pierwszy rok monokultury } \\
1 \text { st year of monoculture }\end{array}$} & \multicolumn{3}{|c|}{$\begin{array}{l}\text { drugi rok monokultury } \\
\text { 2nd year of monoculture }\end{array}$} & \multicolumn{3}{|c|}{$\begin{array}{l}\text { trzeci rok monokultury } \\
\text { 3rd year of monoculture }\end{array}$} \\
\hline & & 147 & 221 & $\begin{array}{l}\text { średnio } \\
\text { mean }\end{array}$ & 147 & 221 & $\begin{array}{c}\text { średnio } \\
\text { mean }\end{array}$ & 147 & 221 & $\begin{array}{c}\text { średnio } \\
\text { mean }\end{array}$ \\
\hline \multirow{3}{*}{ Brak - None } & 400 & 20,4 & 19,6 & 20,0 & 17,1 & 17,2 & 17,2 & 12,8 & 13,2 & 13,0 \\
\hline & 600 & 19,5 & 19,4 & 19,5 & 17,4 & 18,1 & 17,7 & 12,1 & 13,5 & 12,8 \\
\hline & średnio - mean & 19,9 & 19,5 & 19,7 & 17,2 & 17,6 & 17,4 & 12,4 & 13,3 & 12,9 \\
\hline \multirow{3}{*}{ Herbicyd - Herbicide } & 400 & 22,3 & 22,7 & 22,5 & 19,7 & 22,1 & 20,9 & 15,4 & 19,2 & 17,3 \\
\hline & 600 & 22,6 & 23,3 & 22,9 & 21,3 & 22,6 & 21,9 & 16,5 & 20,1 & 18,3 \\
\hline & średnio - mean & 22,4 & 23,0 & 22,7 & 20,5 & 22,4 & 21,4 & 16,0 & 19,7 & 17,8 \\
\hline \multirow{3}{*}{$\begin{array}{l}\text { Herbicyd }+ \text { fungicyd } \\
\text { Herbicide }+ \text { fungicide }\end{array}$} & 400 & 14,6 & 14,9 & 14,8 & 12,1 & 12,2 & 12,2 & 7,4 & 8,6 & 8,0 \\
\hline & 600 & 15,6 & 14,7 & 15,1 & 12,5 & 14,0 & 13,3 & 8,9 & 9,0 & 9,0 \\
\hline & średnio - mean & 15,1 & 14,8 & 14,9 & 12,3 & 13,1 & 12,7 & 8,1 & 8,8 & 8,5 \\
\hline \multirow{3}{*}{ Średnio - Mean } & 400 & 19,1 & 19,1 & 19,1 & 16,3 & 17,2 & 16,7 & 11,9 & 13,7 & 12,8 \\
\hline & 600 & 19,2 & 19,1 & 19,2 & 17,0 & 18,2 & 17,6 & 12,5 & 14,2 & 13,4 \\
\hline & średnio - mean & 19,2 & 19,1 & 19,1 & 16,7 & 17,7 & 17,2 & 12,2 & 13,9 & 13,1 \\
\hline \multicolumn{2}{|l|}{$\operatorname{NIR}(0,05)-\operatorname{LSD}(0.05)$} & \multicolumn{3}{|c|}{$\begin{array}{c}\text { I }-2,767 \\
\text { pozostałe }- \text { other }- \text { r.n. }\end{array}$} & \multicolumn{3}{|c|}{$\begin{array}{c}\text { I - 2,802; II - 0,791; } \\
\text { III - 0,422; I × III - 2,592; } \\
\text { III } \times \text { I }-0,73 ; \\
\text { pozostałe }- \text { other }- \text { r.n. }\end{array}$} & \multicolumn{3}{|c|}{$\begin{array}{c}\text { I }-3,745 ; \text { II }-0,505 ; \\
\text { III }-0,389 ; \text { I } \times \text { II }-3,631 ; \\
\text { II } \times \text { I }-0,867 ; \text { I } \times \text { III }-3,42 \\
\text { III } \times \text { I }-0,674 ; \\
\text { pozostałe }- \text { other }- \text { r.n. }\end{array}$} \\
\hline
\end{tabular}

I - czynnik I (chemiczna ochrona roślin) - factor I (chemical crop protection); II - czynnik II (gęstość siewu) - factor II (sowing density);

III - czynnik III (dawka nawożenia) - factor III (fertilizer dose); r.n. - różnice nieistotne - not significant differences

Tabela 2. Procent powierzchni liści pszenicy z objawami rdzy brunatnej (P. triticina) - średnio z dwóch serii

Table 2. Percentage of wheat leaf surface area with symptoms of brown rust (P. triticina) - mean for two series

\begin{tabular}{|c|c|c|c|c|c|c|c|c|c|c|}
\hline \multirow{3}{*}{$\begin{array}{l}\text { Chemiczna } \\
\text { ochrona roślin } \\
\text { Chemical crop } \\
\text { protection } \\
\text { (I) }\end{array}$} & \multirow{3}{*}{$\begin{array}{l}\text { Gęstość siewu } \\
\text { ziaren } / \mathrm{m}^{2} \\
\text { Sowing density } \\
\text { grains } / \mathrm{m}^{2} \\
\text { (II) }\end{array}$} & \multicolumn{9}{|c|}{ Dawka nawożenia - Fertilizer dose [kg NPK/ha] (III) } \\
\hline & & \multicolumn{3}{|c|}{$\begin{array}{l}\text { pierwszy rok monokultury } \\
1 \text { st year of monoculture }\end{array}$} & \multicolumn{3}{|c|}{$\begin{array}{l}\text { drugi rok monokultury } \\
\text { 2nd year of monoculture }\end{array}$} & \multicolumn{3}{|c|}{$\begin{array}{l}\text { trzeci rok monokultury } \\
\text { 3rd year of monoculture }\end{array}$} \\
\hline & & 147 & 221 & $\begin{array}{l}\text { średnio } \\
\text { mean }\end{array}$ & 147 & 221 & $\begin{array}{c}\text { średnio } \\
\text { mean }\end{array}$ & 147 & 221 & $\begin{array}{c}\text { średnio } \\
\text { mean }\end{array}$ \\
\hline \multirow{3}{*}{ Brak - None } & 400 & 3,75 & 5,39 & 4,57 & 1,10 & 1,15 & 1,13 & 0,83 & 1,04 & 0,93 \\
\hline & 600 & 3,29 & 4,86 & 4,08 & 1,15 & 1,21 & 1,18 & 0,63 & 1,84 & 1,24 \\
\hline & średnio - mean & 3,52 & 5,13 & 4,32 & 1,13 & 1,18 & 1,15 & 0,73 & 1,44 & 1,08 \\
\hline \multirow{3}{*}{ Herbicyd - Herbicide } & 400 & 6,06 & 5,66 & 5,86 & 1,66 & 1,78 & 1,72 & 2,09 & 3,18 & 2,63 \\
\hline & 600 & 5,46 & 5,06 & 5,26 & 1,43 & 1,21 & 1,32 & 2,08 & 3,75 & 2,91 \\
\hline & średnio - mean & 5,76 & 5,36 & 5,56 & 1,54 & 1,49 & 1,52 & 2,09 & 3,46 & 2,77 \\
\hline \multirow{3}{*}{$\begin{array}{l}\text { Herbicyd }+ \text { fungicyd } \\
\text { Herbicide }+ \text { fungicide }\end{array}$} & 400 & 2,31 & 3,70 & 3,01 & 0,00 & 0,00 & 0,00 & 0,74 & 1,29 & 1,02 \\
\hline & 600 & 3,70 & 3,15 & 3,43 & 0,00 & 0,00 & 0,00 & 1,11 & 0,93 & 1,02 \\
\hline & średnio - mean & 3,01 & 3,43 & 3,22 & 0,00 & 0,00 & 0,00 & 0,93 & 1,11 & 1,02 \\
\hline \multirow{3}{*}{ Średnio - Mean } & 400 & 4,04 & 4,92 & 4,48 & 0,92 & 0,98 & 0,95 & 1,22 & 1,84 & 1,53 \\
\hline & 600 & 4,15 & 4,36 & 4,25 & 0,86 & 0,81 & 0,83 & 1,27 & 2,17 & 1,72 \\
\hline & średnio - mean & 4,10 & 4,64 & 4,37 & 0,89 & 0,89 & 0,89 & 1,25 & 2,00 & 1,62 \\
\hline \multicolumn{2}{|l|}{$\operatorname{NIR}(0,05)-\operatorname{LSD}(0.05)$} & \multicolumn{3}{|c|}{\begin{tabular}{|c|}
$\mathrm{I}-0,976 ; \mathrm{III}-0,044 ;$ \\
$\mathrm{I} \times \mathrm{III}-0,883 ; \mathrm{III} \times \mathrm{I}-0,077 ;$ \\
$\mathrm{I} \times \mathrm{III}-0,462 ; \mathrm{III} \times \mathrm{II}-0,063$ \\
$\quad$ pozostałe - other - r.n.
\end{tabular}} & \multicolumn{3}{|c|}{$\begin{array}{c}\mathrm{I}-0,53 \\
\text { pozostałe }- \text { other }- \text { r.n. }\end{array}$} & \multicolumn{3}{|c|}{ r.n. } \\
\hline
\end{tabular}

I - czynnik I (chemiczna ochrona roślin) - factor I (chemical crop protection); II - czynnik II (gęstość siewu) - factor II (sowing density);

III - czynnik III (dawka nawożenia) - factor III (fertilizer dose); r.n. - różnice nieistotne - not significant differences 
Tabela 3. Procent powierzchni liści pszenicy z objawami mączniaka prawdziwego zbóż i traw (B. graminis) - średnio z dwóch serii

Table 3. Percentage of wheat leaf surface area with symptoms of powdery mildew (B. graminis) - mean for two series

\begin{tabular}{|c|c|c|c|c|c|c|c|c|c|c|}
\hline \multirow{3}{*}{$\begin{array}{l}\text { Chemiczna } \\
\text { ochrona roślin } \\
\text { Chemical crop } \\
\text { protection } \\
\text { (I) }\end{array}$} & \multirow{3}{*}{$\begin{array}{l}\text { Gęstość siewu } \\
\text { ziaren } / \mathrm{m}^{2} \\
\text { Sowing density } \\
\text { grains } / \mathrm{m}^{2} \\
\text { (II) }\end{array}$} & \multicolumn{9}{|c|}{ Dawka nawożenia - Fertilizer dose [kg NPK/ha] (III) } \\
\hline & & \multicolumn{3}{|c|}{$\begin{array}{l}\text { pierwszy rok monokultury } \\
1 \text { st year of monoculture }\end{array}$} & \multicolumn{3}{|c|}{$\begin{array}{l}\text { drugi rok monokultury } \\
\text { 2nd year of monoculture }\end{array}$} & \multicolumn{3}{|c|}{$\begin{array}{l}\text { trzeci rok monokultury } \\
\text { 3rd year of monoculture }\end{array}$} \\
\hline & & 147 & 221 & $\begin{array}{l}\text { średnio } \\
\text { mean }\end{array}$ & 147 & 221 & $\begin{array}{l}\text { średnio } \\
\text { mean }\end{array}$ & 147 & 221 & $\begin{array}{c}\text { średnio } \\
\text { mean }\end{array}$ \\
\hline \multirow{3}{*}{ Brak - None } & 400 & 1,73 & 1,56 & 1,64 & 4,50 & 6,11 & 5,31 & 2,50 & 4,15 & 3,33 \\
\hline & 600 & 1,56 & 2,59 & 2,08 & 5,28 & 7,76 & 6,52 & 3,06 & 4,18 & 3,62 \\
\hline & średnio - mean & 1,64 & 2,08 & 1,86 & 4,89 & 6,94 & 5,91 & 2,78 & 4,16 & 3,47 \\
\hline \multirow{3}{*}{ Herbicyd - Herbicide } & 400 & 0,98 & 1,94 & 1,46 & 3,41 & 8,05 & 5,73 & 2,21 & 3,34 & 2,78 \\
\hline & 600 & 1,46 & 1,66 & 1,56 & 4,78 & 11,65 & 8,21 & 2,78 & 4,73 & 3,75 \\
\hline & średnio - mean & 1,22 & 1,80 & 1,51 & 4,09 & 9,85 & 6,97 & 2,49 & 4,03 & 3,26 \\
\hline \multirow{3}{*}{$\begin{array}{l}\text { Herbicyd }+ \text { fungicyd } \\
\text { Herbicide }+ \text { fungicide }\end{array}$} & 400 & 0,00 & 0,55 & 0,28 & 1,38 & 2,49 & 1,93 & 0,55 & 1,66 & 1,11 \\
\hline & 600 & 0,00 & 0,83 & 0,41 & 1,10 & 2,63 & 1,86 & 0,55 & 1,94 & 1,24 \\
\hline & średnio - mean & 0,00 & 0,69 & 0,34 & 1,24 & 2,56 & 1,90 & 0,55 & 1,80 & 1,18 \\
\hline \multirow{3}{*}{ Średnio - Mean } & 400 & 0,90 & 1,35 & 1,13 & 3,10 & 5,55 & 4,32 & 1,75 & 3,05 & 2,40 \\
\hline & 600 & 1,01 & 1,69 & 1,35 & 3,72 & 7,35 & 5,53 & 2,13 & 3,61 & 2,87 \\
\hline & średnio - mean & 0,95 & 1,52 & 1,24 & 3,41 & 6,45 & 4,93 & 1,94 & 3,33 & 2,64 \\
\hline $\operatorname{NIR}(0,05)-\operatorname{LSD}(0.05)$ & & \multicolumn{3}{|c|}{$\begin{array}{l}\text { I - 1,404; III - 0,354; } \\
\text { pozostałe - other - r.n. }\end{array}$} & \multicolumn{3}{|c|}{$\begin{array}{c}\text { I - 3,473; II - 1,144; } \\
\text { III - 1,035; I × III - 3,431; } \\
\text { III } \times \text { I }-1,793 ; \\
\text { pozostałe }- \text { other }- \text { r.n. }\end{array}$} & \multicolumn{3}{|c|}{$\begin{array}{c}\text { I - 1,408; II - 0,517; } \\
\text { III - 0,158; } \\
\text { pozostałe - other - r.n. }\end{array}$} \\
\hline
\end{tabular}

I - czynnik I (chemiczna ochrona roślin) - factor I (chemical crop protection); II - czynnik II (gęstość siewu) - factor II (sowing density);

III - czynnik III (dawka nawożenia) - factor III (fertilizer dose); r.n. - różnice nieistotne - not significant differences

Tabela 4. Procent powierzchni liści pszenicy z objawami brunatnej plamistości liści ( $P$. tritici-repentis) - średnio z dwóch serii Table 4. Percentage of wheat leaf surface area with symptoms of tan spot (P. tritici-repentis) - mean for two series

\begin{tabular}{|c|c|c|c|c|c|c|c|c|c|c|}
\hline \multirow{3}{*}{$\begin{array}{l}\text { Chemiczna } \\
\text { ochrona roślin } \\
\text { Chemical crop } \\
\text { protection } \\
\text { (I) }\end{array}$} & \multirow{3}{*}{$\begin{array}{l}\text { Gęstość siewu } \\
\text { ziaren } / \mathrm{m}^{2} \\
\text { Sowing density } \\
\text { grains } / \mathrm{m}^{2} \\
\text { (II) }\end{array}$} & \multicolumn{9}{|c|}{ Dawka nawożenia - Fertilizer dose [kg NPK/ha] (III) } \\
\hline & & \multicolumn{3}{|c|}{$\begin{array}{l}\text { pierwszy rok monokultury } \\
1 \text { st year of monoculture }\end{array}$} & \multicolumn{3}{|c|}{$\begin{array}{l}\text { drugi rok monokultury } \\
\text { 2nd year of monoculture }\end{array}$} & \multicolumn{3}{|c|}{$\begin{array}{l}\text { trzeci rok monokultury } \\
\text { 3rd year of monoculture }\end{array}$} \\
\hline & & 147 & 221 & $\begin{array}{l}\text { średnio } \\
\text { mean }\end{array}$ & 147 & 221 & $\begin{array}{l}\text { średnio } \\
\text { mean }\end{array}$ & 147 & 221 & $\begin{array}{c}\text { średnio } \\
\text { mean }\end{array}$ \\
\hline \multirow{3}{*}{ Brak - None } & 400 & 0,18 & 0,31 & 0,25 & 1,10 & 1,15 & 1,13 & 0,91 & 2,48 & 1,69 \\
\hline & 600 & 0,24 & 0,33 & 0,29 & 1,15 & 1,43 & 1,29 & 1,51 & 2,20 & 1,86 \\
\hline & średnio - mean & 0,21 & 0,32 & 0,27 & 1,13 & 1,29 & 1,21 & 1,21 & 2,34 & 1,78 \\
\hline \multirow{3}{*}{ Herbicyd - Herbicide } & 400 & 0,55 & 0,64 & 0,60 & 1,10 & 1,43 & 1,26 & 4,99 & 6,65 & 5,82 \\
\hline & 600 & 0,58 & 0,71 & 0,65 & 1,10 & 1,15 & 1,13 & 5,28 & 8,06 & 6,67 \\
\hline & średnio - mean & 0,57 & 0,68 & 0,62 & 1,10 & 1,29 & 1,19 & 5,13 & 7,36 & 6,24 \\
\hline \multirow{3}{*}{$\begin{array}{l}\text { Herbicyd }+ \text { fungicyd } \\
\text { Herbicide }+ \text { fungicide }\end{array}$} & 400 & 0,15 & 0,23 & 0,19 & 0,00 & 0,00 & 0,00 & 1,38 & 2,75 & 2,06 \\
\hline & 600 & 0,23 & 0,20 & 0,22 & 0,00 & 0,00 & 0,00 & 2,58 & 2,20 & 2,39 \\
\hline & średnio - mean & 0,19 & 0,22 & 0,20 & 0,00 & 0,00 & 0,00 & 1,98 & 2,48 & 2,23 \\
\hline \multirow{3}{*}{ Średnio - Mean } & 400 & 0,30 & 0,39 & 0,34 & 0,73 & 0,86 & 0,80 & 2,43 & 3,96 & 3,19 \\
\hline & 600 & 0,35 & 0,41 & 0,38 & 0,75 & 0,86 & 0,80 & 3,12 & 4,15 & 3,64 \\
\hline & średnio - mean & 0,32 & 0,40 & 0,36 & 0,74 & 0,86 & 0,80 & 2,77 & 4,06 & 3,42 \\
\hline \multicolumn{2}{|l|}{$\operatorname{NIR}(0,05)-\operatorname{LSD}(0.05)$} & \multicolumn{3}{|c|}{ r.n. } & \multicolumn{3}{|c|}{$\begin{array}{c}\mathrm{I}-0,381 \\
\text { pozostałe }- \text { other }- \text { r.n. }\end{array}$} & \multicolumn{3}{|c|}{$\begin{array}{l}\text { I - 2,393; III - 0,504; } \\
\text { I } \times \text { III }-2,264 ; \text { III } \times \text { I }-0,713 ; \\
\text { pozostałe }- \text { other }- \text { r.n }\end{array}$} \\
\hline
\end{tabular}

I - czynnik I (chemiczna ochrona roślin) - factor I (chemical crop protection); II - czynnik II (gęstość siewu) - factor II (sowing density);

III - czynnik III (dawka nawożenia) - factor III (fertilizer dose); r.n. - różnice nieistotne - not significant differences 
Tabela 5. Procent powierzchni kłosów z objawami septoriozy plew pszenicy (P. nodorum) - średnio z dwóch serii

Table 5. Percentage of wheat ear surface area with symptoms of glume blotch (P. nodorum) - mean for two series

\begin{tabular}{|c|c|c|c|c|c|c|c|c|c|c|}
\hline \multirow{3}{*}{$\begin{array}{l}\text { Chemiczna } \\
\text { ochrona roślin } \\
\text { Chemical crop } \\
\text { protection } \\
\text { (I) }\end{array}$} & \multirow{3}{*}{$\begin{array}{l}\text { Gęstość siewu } \\
\text { ziaren } / \mathrm{m}^{2} \\
\text { Sowing density } \\
\text { grains } / \mathrm{m}^{2} \\
\text { (II) }\end{array}$} & \multicolumn{9}{|c|}{ Dawka nawożenia - Fertilizer dose [kg NPK/ha] (III) } \\
\hline & & \multicolumn{3}{|c|}{$\begin{array}{l}\text { pierwszy rok monokultury } \\
1 \text { st year of monoculture }\end{array}$} & \multicolumn{3}{|c|}{$\begin{array}{l}\text { drugi rok monokultury } \\
\text { 2nd year of monoculture }\end{array}$} & \multicolumn{3}{|c|}{$\begin{array}{l}\text { trzeci rok monokultury } \\
\text { 3rd year of monoculture }\end{array}$} \\
\hline & & 147 & 221 & $\begin{array}{l}\text { średnio } \\
\text { mean }\end{array}$ & 147 & 221 & $\begin{array}{c}\text { średnio } \\
\text { mean }\end{array}$ & 147 & 221 & $\begin{array}{c}\text { średnio } \\
\text { mean }\end{array}$ \\
\hline \multirow{3}{*}{ Brak - None } & 400 & 0,66 & 0,56 & 0,61 & 0,65 & 0,56 & 0,61 & 0,83 & 1,43 & 1,13 \\
\hline & 600 & 0,56 & 0,10 & 0,33 & 0,63 & 0,10 & 0,36 & 0,05 & 1,10 & 0,58 \\
\hline & średnio - mean & 0,61 & 0,33 & 0,47 & 0,64 & 0,33 & 0,48 & 0,44 & 1,26 & 0,85 \\
\hline \multirow{3}{*}{ Herbicyd - Herbicide } & 400 & 1,71 & 1,73 & 1,72 & 1,08 & 1,29 & 1,18 & 12,23 & 12,29 & 12,26 \\
\hline & 600 & 1,60 & 1,83 & 1,71 & 1,23 & 1,40 & 1,31 & 10,11 & 13,33 & 11,72 \\
\hline & średnio - mean & 1,66 & 1,78 & 1,72 & 1,15 & 1,34 & 1,25 & 11,17 & 12,81 & 11,99 \\
\hline \multirow{3}{*}{$\begin{array}{l}\text { Herbicyd }+ \text { fungicyd } \\
\text { Herbicide }+ \text { fungicide }\end{array}$} & 400 & 0,51 & 0,98 & 0,74 & 0,14 & 0,14 & 0,14 & 4,71 & 5,00 & 4,86 \\
\hline & 600 & 0,46 & 0,98 & 0,72 & 0,10 & 0,55 & 0,33 & 5,28 & 5,61 & 5,44 \\
\hline & średnio - mean & 0,49 & 0,98 & 0,73 & 0,12 & 0,34 & 0,23 & 4,99 & 5,31 & 5,15 \\
\hline \multirow{3}{*}{ Średnio - Mean } & 400 & 0,96 & 1,09 & 1,03 & 0,62 & 0,66 & 0,64 & 5,92 & 6,24 & 6,08 \\
\hline & 600 & 0,88 & 0,97 & 0,92 & 0,65 & 0,68 & 0,67 & 5,15 & 6,68 & 5,91 \\
\hline & średnio - mean & 0,92 & 1,03 & 0,97 & 0,64 & 0,67 & 0,65 & 5,53 & 6,46 & 6,00 \\
\hline \multicolumn{2}{|l|}{$\operatorname{NIR}(0,05)-\operatorname{LSD}(0.05)$} & \multicolumn{3}{|c|}{\begin{tabular}{|l}
$\mathrm{I}-0,769 ; \mathrm{III}-0,038$ \\
$\mathrm{I} \times \mathrm{III}-0,696 ; \mathrm{III} \times \mathrm{I}-0,067$ \\
$\quad$ pozostałe - other - r.n
\end{tabular}} & \multicolumn{3}{|c|}{$\begin{array}{c}\mathrm{I}-0,684 ; \mathrm{I} \times \mathrm{III}-0,62 \\
\mathrm{III} \times \mathrm{I}-0,074 ; \\
\text { pozostałe }- \text { other }- \text { r.n. }\end{array}$} & \multicolumn{3}{|c|}{$\begin{array}{c}\text { I - 9,924; } \\
\text { pozostałe - other - r.n. }\end{array}$} \\
\hline
\end{tabular}

I - czynnik I (chemiczna ochrona roślin) - factor I (chemical crop protection); II - czynnik II (gęstość siewu) - factor II (sowing density);

III - czynnik III (dawka nawożenia) - factor III (fertilizer dose); r.n. - różnice nieistotne - not significant differences

gęstość siewu. Najmniej objawów septoriozy paskowanej liści pszenicy (tab. 1) oraz mączniaka prawdziwego zbóż i traw (tab. 3) we wszystkich kolejnych latach uprawy pszenicy oraz rdzy brunatnej (tab. 2) w dwóch pierwszych latach uprawy, stwierdzono po zastosowaniu fungicydu (Alert 375 SC) i herbicydu (Huzar 05 WG). Stosowanie tych preparatów nie ograniczało występowania septoriozy plew pszenicy (tab. 5) we wszystkich latach uprawy oraz brunatnej plamistości liści (tab. 4) w trzecim roku uprawy pszenicy, w porównaniu do zaniechania chemicznej ochrony. Zastosowanie samego herbicydu powodowało istotny wzrost nasilenia objawów septoriozy paskowanej liści oraz septoriozy plew pszenicy we wszystkich latach uprawy pszenicy $\mathrm{w}$ monokulturze, $\mathrm{w}$ pierwszym roku uprawy także rdzy brunatnej, a w trzecim brunatnej plamistości liści, w porównaniu do obiektów bez ochrony chemicznej.

W literaturze podkreśla się wysoką skuteczność ochrony fungicydowej pszenicy ozimej przed chorobami grzybowymi zbóż (Głazek i wsp. 2005; HoroszkiewiczJanka i wsp. 2012). W badaniach własnych nie dla wszystkich chorób potwierdziło się to. Można to tłumaczyć zakresem działania stosowanego $\mathrm{w}$ badaniach własnych preparatu Alert 375 SC, który w pszenicy ozimej zarejestrowany jest do zwalczania mączniaka prawdziwego zbóż i traw, rdzy brunatnej, septoriozy paskowanej liści i septoriozy plew pszenicy (Zalecenia 2008/2009). Według Edwardsa i Dodgsona (2009) zawarty w preparacie flusilazol skutecznie zwalcza $P$. nodorum, średnio skutecznie B. graminis, M. graminicola i P. triticina, natomiast karbendazym wykazuje bardzo słabą skuteczność wobec wszystkich patogenów obserwowanych na pszenicy. Ograniczona skuteczność fungicydu Alert 375 SC w stosunku do niektórych patogenów wynikała zapewne również z faktu, że został on zastosowany już pod koniec fazy strzelania $\mathrm{w}$ źdźbło, a niektóre patogeny pojawily się znacznie później, kiedy biologiczna aktywność preparatu prawdopodobnie była już znacznie mniejsza. Słabą skuteczność stwierdzono zwłaszcza w ograniczaniu porażenia pszenicy przez $P$. nodorum i $P$. tritici-repentis, które to na poletkach kontrolnych pojawiły się dopiero $\mathrm{w}$ fazie kwitnienia lub dojrzewania pszenicy. $Z$ tego wynika, że $\mathrm{w}$ warunkach silnej presji patogenów, również $\mathrm{w}$ warunkach gleby słabszej, jednorazowe zastosowanie fungicydu w sezonie wegetacyjnym może być niewystarczające by skutecznie chronić przed wszystkimi chorobami. W takich sytuacjach należałoby rozważyć możliwość ponownego zastosowania ochrony fungicydowej.

$\mathrm{Na}$ istotny wpływ herbicydów na występowanie chorób w pszenicy ozimej wskazują również inni autorzy (Katan i Eshel 1973; Altman i Campbell 1977; Altman i Rovira 1989; Lévesque i Rahe 1992; Wisler i Norris 2005). Obserwuje się to głównie w stosunku do patogenów rozwijających się w glebie. W badaniach własnych udowodniono istotny wpływ stosowania herbicydu na wzmożone występowanie chorób na liściach oraz kłosach. Również w pracy Lemańczyka i Jaskulskiego (2006) na pszenicy ozimej obserwowano znacznie więcej objawów rdzy brunatnej i septoriozy paskowanej liści pszenicy po zastosowaniu herbicydu Chwastox Trio 540 SL (mekoprop + MCPA + dikamba). Altman i Campbell (1977) podają, iż 
stosowanie herbicydów może przyczyniać się do wzmożonego występowania mączniaka prawdziwego zbóż i traw, co nie potwierdziło się $\mathrm{w}$ badaniach własnych oraz Lemańczyka i Jaskulskiego (2006). Kurowski i wsp. (2010) zaobserwowali natomiast spadek nasilenia septoriozy paskowanej liści pszenicy oraz rdzy brunatnej po zastosowaniu preparatu Mustang 306 SL (florasulam). Zgodnie z Lévesque i Rahe (1992) herbicydy mogły wpływać na zdrowotność roślin również pośrednio. Zaniechanie stosowania herbicydów przyczynia się do znacznego rozwoju chwastów, co obserwuje się zwłaszcza w kolejnych latach uprawy pszenicy (Piekarczyk 2010b). To zapewne sprawiło, że mikroklimat panujący w łanie był mniej sprzyjający dla rozwoju patogenów liści i kłosów.

W badaniach własnych gęstość siewu pszenicy głównie różnicowała występowanie septoriozy paskowanej liści pszenicy, w mniejszym stopniu mączniaka prawdziwego zbóż i traw i rdzy brunatnej. W drugim i trzecim roku uprawy pszenicy w monokulturze istotnie więcej objawów septoriozy paskowanej liści pszenicy obserwowano, gdy wysiewano 600 ziaren pszenicy na $\mathrm{m}^{2} \mathrm{w}$ porównaniu z 400 ziarnami na $\mathrm{m}^{2}$. Zwiększenie ilości wysiewu ziaren spowodowało również istotny wzrost występowania mączniaka prawdziwego zbóż i traw w drugim roku uprawy oraz spadek występowania rdzy brunatnej przy wyższym nawożeniu NPK.

Gęsty siew sprawia, że rośliny są bliżej siebie, co znacznie ułatwia rozprzestrzenianie patogenów (Walters 2009). Ponadto gęstość siewu może wpływać również w sposób pośredni na nasilenie chorób, między innymi poprzez zmianę mikroklimatu panującego w łanie. W gęstych zasiewach temperatura jest bardziej jednolita, panuje wyższa wilgotność powietrza, a na liściach utrzymuje się dłużej woda, co znacznie sprzyja porażeniu roślin przez patogeny.

$\mathrm{Na}$ występowanie chorób statystycznie istotnie wpływało nawożenie mineralne pszenicy. We wszystkich latach uprawy pszenicy zwiększenie dawki nawożenia mineralnego z 147 do $221 \mathrm{~kg}$ NPK/ha powodowało wzmożone występowanie mączniaka prawdziwego zbóż i traw. W pierwszym roku uprawy zwiększenie dawki nawożenia przyczyniło się do istotnego wzrostu nasilenia rdzy brunatnej i septoriozy plew pszenicy, w drugim i trzecim również septoriozy paskowanej liści, a w trzecim brunatnej plamistości liści.

Zazwyczaj dobrze nawożone rośliny cechują się wyższą odpornością na porażenie przez patogeny (Smiley i wsp. 1996). W badaniach własnych nie potwierdziło się to. Również Rowaished (1980) obserwował istotny wzrost porażenia pszenicy przez $B$. graminis przy zwiększonych dawkach nawożenia azotem i fosforem, natomiast wyższe dawki potasu ograniczały porażenie. Prawdopodobnie lepiej odżywione rośliny zapewniały również korzystniejsze warunki dla rozwoju patogenów rozwijających się na liściach i kłosach. Może to być szczególnie ważne w uprawach pszenicy na glebach słabszych, zwłaszcza uprawianych po sobie, gdyż w takich warunkach łan jest mniej zwarty, co nie sprzyja występowaniu chorób. Tego typu efekt obserwuje się zwłaszcza przy zmniejszonych dawkach nawożenia azotem (Walters 2009).

\section{Wnioski / Conclusions}

1. Uprawa pszenicy ozimej w krótkotrwałej monokulturze na glebie lekkiej spowodowała wzrost występowania objawów brunatnej plamistości liści oraz spadek nasilenia septoriozy paskowanej liści pszenicy.

2. Na występowanie chorób istotnie wpływała ochrona chemiczna. Najniższe nasilenie chorób obserwowano po zastosowaniu fungicydu i herbicydu. Stosowanie samego herbicydu sprzyjało występowaniu chorób, zwłaszcza septoriozy liści oraz septoriozy plew pszenicy.

3. Udowodniono wzrost nasilenia septoriozy paskowanej liści pszenicy i mączniaka prawdziwego zbóż i traw przy zwiększeniu gęstości siewu pszenicy ozimej z 400 do 600 ziaren na $\mathrm{m}^{2}$.

4. Zwiększenie dawki nawożenia mineralnego z 147 do $221 \mathrm{~kg} \mathrm{NPK} /$ ha powodowało wzmożone występowanie obserwowanych chorób.

\section{Literatura / References}

Altman J., Campbell C.L. 1977. Effect of herbicides on plant diseases. Annu. Rev. Phytopathol. 15: 361-385.

Altman J., Rovira A.D. 1989. Herbicide-pathogen interactions in soil-borne root diseases. Can. J. Plant Pathol. 11 (2): $166-172$.

Dyrektywa 2009/128/WE. Dziennik Urzędowy Unii Europejskiej z dnia 24.11.2009. Dyrektywa Parlamentu Europejskiego i Rady 2009/128/WE z dnia 21.10.2009 r.: 71-86.

Edwards C., Dodgson G. (eds.). 2009. The wheat disease management guide 2009. 4th edition. Londyn. AHDB-HGCA. www.hgca.com, accessed: 28.08.2009.

Głazek M., Krzyzińska B., Mączyńska A. 2005. Occurrence of Stagonospora nodorum glume blotch of wheat in the region of middle southern Poland. Acta Agrobot. 58 (1): 23-28.

Horoszkiewicz-Janka J., Jajor E., Korbas M. 2012. Występowanie chorób pszenicy ozimej w zależności od wybranych czynników agrotechnicznych. [Prevalence of winter wheat diseases depending on selected agrotechnical factors]. Prog. Plant Prot./Post. Ochr. Roślin 52 (4): 998-1004.

Katan J., Eshel Y. 1973. Interactions between herbicides and plant pathogens. Residue Rev. 45: 145-177.

Korbas M., Mrówczynski M., Paradowski A., Horoszkiewicz-Janka J., Jajor E., Pruszyński G. 2008. Ochrona roślin w integrowanej produkcji pszenicy. [Plant protection in integrated wheat production]. Prog. Plant Prot./Post. Ochr. Roślin 48 (4): 1502-1515.

Kurowski T.P., Brzozowska I., Brzozowski J., Kurowska A. 2010. Zdrowotność pszenżyta ozimego w zależności od sposobu regulacji zachwaszczenia, nawożenia azotem i ochrony przed patogenami. [Health status of winter triticale as dependent on weed control, nitrogen fertilization and protection against pathogens]. Ann. UMCS, Sec. E, Agricultura 65 (2): 10-22. 
Lemańczyk G. 2012. Chemiczne zwalczanie chwastów a nasilenie chorób korzeni i podstawy źdźbła zbóż jarych. [Severity of root and stem base diseases of spring cereals as affected by chemical control of weeds]. Prog. Plant Prot./Post. Ochr. Roślin 52 (2): 369-376.

Lemańczyk G., Jaskulski D. 2006. Wpływ zwalczania chwastów i przedplonu na zdrowotność liści pszenicy ozimej i pszenżyta ozimego. [Effect of weed control and forecrop on health condition of wheat and winter triticale]. Prog. Plant Prot./Post. Ochr. Roślin 46 (2): 149-152.

Lemańczyk G., Piekarczyk M. 2010. Zdrowotność pszenicy ozimej uprawianej na glebie lekkiej w zależności od przedplonu i dawki nawożenia azotowego. [Health status of winter wheat grown on a light soil depending on previous crop and dose of nitrogen fertilization]. Prog. Plant Prot./Post. Ochr. Roślin 50 (2): 922-926.

Lévesque C.A., Rahe J.E. 1992. Herbicide interactions with fungal root pathogens, with special reference to glyphosate. Annu. Rev. Phytopathol. 30: 579-602.

Mikołajska J. 1993. Płodozmian a zdrowotność roślin. s. 25-33. W: Materiały z Konferencji „Biotyczne środowisko uprawne a zagrożenie chorobowe roślin". AR-T Olsztyn, 7-9 września 1993, 468 ss.

Piekarczyk M. 2010a. Effect of fertilisation dose, plant protection input, and seeding density on the yield and grain technological quality of winter wheat grown in short-time monoculture on light soil. Acta Sci. Pol., Agricultura 9 (2): 15-23.

Piekarczyk M. 2010b. Wpływ poziomu nawożenia, ochrony roślin i gęstości siewu na zachwaszczenie pszenicy ozimej uprawianej w krótkotrwałej monokulturze. [Effect of fertilisation dose, plant protection input and sowing rate of winter wheat on weed infestation in short-time monoculture]. Ann. UMCS, Sec. E, Agricultura 65 (2): 48-57.

Rowaished A.K. 1980. Effect of NPK fertilizer on powdery mildew incidence in winter wheat. Cereal Res. Commun. 8 (3): $559-566$.

Smiley R.W., Collins H.P., Rasmussen P.E. 1996. Diseases of wheat in long-term agronomic experiments at Pendelton, Oregon. Plant Dis. 80 (7): 813-820.

Velini E.D., Trindade M.L.B., Barberis L.R.M., Duke S.O. 2010. Growth regulation and other secondary effects of herbicides. Weed Sci. 58 (3): 351-354.

Walters D. (ed.). 2009. Disease Control in Crops: Biological and Environmentally Friendly Approaches. John Wiley \& Sons, Edinburgh, UK, 226 pp.

Wisler G.C., Norris R.F. 2005. Interactions between weeds and cultivated plants as related to management of plant pathogens. Weed Sci. 53 (6): 914-917.

Zalecenia Ochrony Roślin na lata 2008/2009. Cz. II, Rośliny Rolnicze. 2008. Inst. Ochr. Roślin, Poznań, 349 ss. 